\title{
Perception of the Environmental Degradation of Gold Mining on Socio-Economic Variables in Eastern Cameroon, Cameroon
}

\author{
Marc Anselme Kamga 1,2*, Charles Olufisayo Olatubara ${ }^{3}$, Moses Monday Atteh 4, Serge Nzali 5 , \\ Adeola Adenikinju ${ }^{6}$, Théodore Yimgnia Mbiatso ${ }^{2}$, Ralain Bryan Ngatcha 7 \\ ${ }^{1}$ Department of Environmental Management, Pan African University Life and Earth Sciences Institute (PAULESI), \\ University of Ibadan, Ibadan, NIGERIA \\ ${ }^{2}$ Department of Earth Sciences, Faculty of Science, University of Yaounde I, CAMEROON \\ ${ }^{3}$ Department of Urban and Regional Planning, Faculty of the Social Sciences, University of Ibadan, Ibadan, NIGERIA \\ ${ }^{4}$ Department of Geography, Faculty of Social Sciences, University of Ibadan, Ibadan, NIGERIA \\ ${ }_{5}^{5}$ School of Wood, Water and Natural Resources, Faculty of Agronomy and Agricultural Sciences, University of Dschang, \\ Ebolowa Campus, Ebolowa, CAMEROON \\ ${ }^{6}$ Centre for Petroleum, Energy Economics and Law, Department of Economics, University of Ibadan, Ibadan, NIGERIA \\ ${ }^{7}$ Department of Geology, Pan African University Life and Earth Sciences Institute (PAULESI), University of Ibadan, \\ Ibadan, NIGERIA
}

\section{*Corresponding Author: mkamga0113@stu.ui.edu.ng}

Citation: Kamga, M. A., Olatubara, C. O., Atteh, M. M., Nzali, S., Adenikinju, A., Mbiatso, T. Y. and Ngatcha, R. B. (2018). Perception of the Environmental Degradation of Gold Mining on Socio-Economic Variables in Eastern Cameroon, Cameroon. European Journal of Sustainable Development Research, 2(2), 23. https://doi.org/10.20897/ejosdr/85117

Published: March 11, 2018

\begin{abstract}
Artisanal mining is associated with a number of environmental impacts, including deforestation and land degradation, open pits which pose animal traps and health hazards, and heavy metals contamination of land (water and soil), dust and noise pollution. The study examines the perception of environmental degradation of gold mining sites in eastern Cameroon. Human-environment interaction and distance decay models are the conceptual framework for this study. This study employed a survey research design through the use of primary data while a purposive sampling technique was utilized. A total of 440 questionnaires were administered to selected households across the localities in the study area. Frequencies, percentages, chart, cross tabulations and chi-square tests were used for the data analysis. In other to achieve the aim of this study, a comparison between the nearby and far away residents were done. The study revealed that mining exploitations have brought about changes in the colour and taste of water in the active mining sites $(41.7 \%)$. Malaria is the number one type of disease that has caused more damage in the localities $(81.6 \%)$. Mining activities have successfully enabled children in the active mining sites to abandoned school for mining $(75.0 \%)$. Inhabitants of unit 1 directly linked the problems facing their economic activities to inadequate arable land for agriculture $(33.8 \%)$ and inhabitants across the study area correlated the problems facing livestock farming to diseases as a result of mining activities (64.6\%). The perceived negative effects of gold mining on different socio-economic variables (such as culture, health, education, economy and livestock) vary significantly depending on the proximity from the mining areas $(p<0.05)$. The study concludes that residents living within and far away from the active mining sites were affected by gold mining activities. However, the most worrisome situation concern people working and living within the active mining sites. Therefore, the study recommends that: companies that are involved in mining activities and the government should embark on development projects such as portable water, schools, hospitals, roads, markets, communications facilities in the affected communities.
\end{abstract}


Keywords: gold mining, perception, environmental degradation, socio-economic variables, eastern Cameroon

\section{INTRODUCTION}

Mining is a major economic activity in many developing countries (Tauli-Corpus, 1997; UNEP, 1997). Operations, whether small or large-scale, are inherently disruptive to the environment (Makweba et al., 1996), producing enormous quantities of waste that can have deleterious impacts for decades (UNEP, 1997). The environmental deterioration caused by mining occurs mainly as a result of inappropriate and wasteful working practices and rehabilitation measures.

Mining has a number of common stages or activities, each of which has potentially-adverse impacts on the natural environment, society, cultural heritage, health and safety of mine workers and that of communities in close proximity to mining operations (Moody et al., 1997). As indicated by Noronha (2001), the social and environmental impacts are more pervasive in regions where operations are newly-established or are closing down.

Sustainable development of mineral resources has become a major challenge for today's global world, addressed to mining companies, scientists associated with mining and many other institutions and organizations. According to Dubiński (2013), the sustainable development of mining is the key to the security of raw materials and energy for many countries in the world.

Cameroon is often referred to as the "hinge of Africa" for its central location in the continent of Africa and was chosen as case study because it has a strong geological potential for a number of minerals resources that, if well managed, could support economic growth through development of the mining sector. The country contains large potential mineral deposits resources. Despite this geological wealth, mining has never played a major role in Cameroon's development, and remains on the margins of the economy.

Artisanal mining constitutes the basis of community's livelihoods in the eastern, southern and northern parts of the country rich in gold and precious stones. However, inadequate regularization prevents the sector to really contribute to economic growth. Awudi (2002), stated that extractive companies have been found to be largely responsible for vegetation clearance and land degradation, waste disposal, mineral processing and misuse of mining chemicals leading to streams and river pollution thus diminishing safe drinking water for humans and loss of biodiversity due to decreasing forest cover. This assertion is exactly what is happening in the gold mining communities in the East region of Cameroon.

Despite the widespread documentation of geological survey and increased mineral production within the East Region of Cameroon, one of the critical limitations observed has to do with the ignorance of the local indigenous communities of the adverse effects of environmental degradation that arise from mining activities and the lack of national legislations and policies to guarantee the sustainable land management. Creating awareness as well as enforcing education on these aspects is of great importance towards environmental sustainability.

Apart from poor environmental governance as highlighted in the Africa Mining Vision, many African countries lack a precise assessment of the impacts of abandoned and active mining activities in their territories. It is therefore crucial to undertake an assessment of the true extent of the detrimental effects of metal pollutants from mining sites and their impact on the environment as well as on human health. This is a pre-requisite for appropriate legislation development and enforcement.

The environmental degradation due to mineral exploitation has been researched by many scholars. Some of them include Chachange (1995), Duraiappah (1998), McMahon (2001), Muezzinoglu (2003), Traore, (2015), Nodem (2016). They widely discussed the review of environmental considerations on gold mining. While there is an abundance of cross-sectional studies looking at exposures and impacts at specific time points and locations, there is a lack of cross-sectional studies examining perception on how exposures and impacts vary with proximity to active mining sites. Cross-sectional study could focus on perception based on proximity to active mining sites within the same regions or on the same people exposed to different environments as they move, work and live in the active mining areas. This study aims at analysing the perception of the environmental degradation of gold mining activities in eastern Cameroon. This is done by examining their impacts on different socio-economic variables depending on the proximity from the active mining sites. It is on these bases that strategies would be adopted for sustainable land management. 


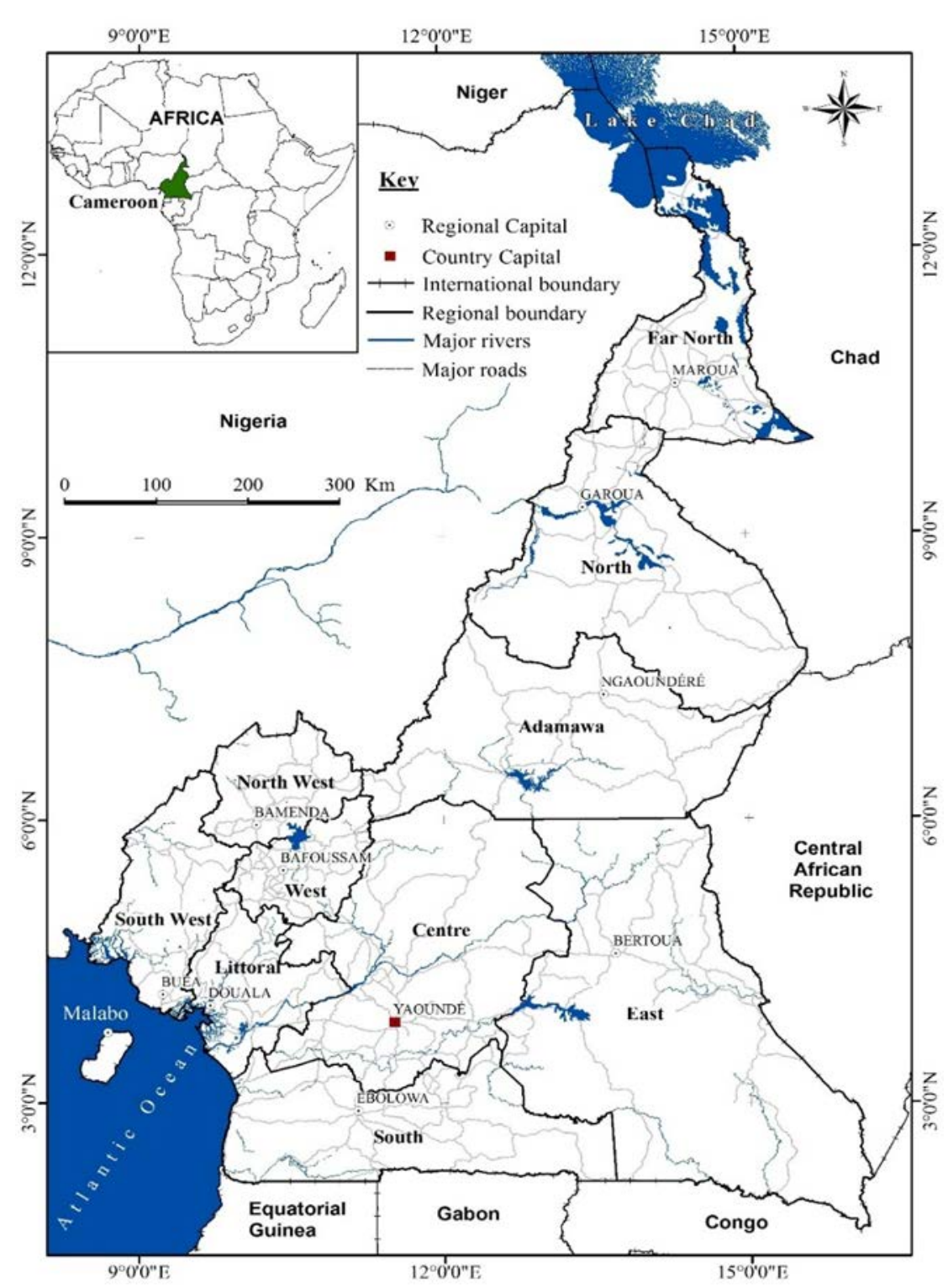

Figure 1. Location of Cameroon in Africa

Source: World Resources Institute, 2014

\section{STUDY AREA}

The Republic of Cameroon is located in Central Africa (Figure 1). It traverses the boundary between West and Central Africa, covering an area of $475,400 \mathrm{~km}^{2}$ (including $2,730 \mathrm{~km}^{2}$ of water). Cameroon shares land boundaries with Nigeria $(1,690 \mathrm{~km})$ to the west, Chad $(1,094 \mathrm{~km})$ to the north and east, Central African Republic $(797 \mathrm{~km})$ to the east, Congo $(523 \mathrm{~km})$ to the east and south, and Gabon $(298 \mathrm{~km})$ and Equatorial Guinea $(189 \mathrm{~km})$ to the south. It is bound to the southwest by the Atlantic Ocean (CIA, 2009). Cameroon is also known as "Africa in miniature" because it represents the confluence of Africa's rich geographic and cultural diversity (Ayuk, 2001).

Topographic variations and the Atlantic Ocean bordering the south-western coastline locally modify the regional climates, imposing different sub-climatic conditions (Asaah, 2010) including the Sudano-Saheline zones in the north, the humid tropical forest of the Congo-Basin in the south and the Savannah grassland zones in the west of the country (Gaston, 2009; Tsalefac, 2007). Cameroon has the second largest (after the Democratic Republic of Congo) freshwater reservoirs (lakes and rivers) in Africa (Mafany et al., 2006). Groundwater aquifers occur within the crystalline basement and in volcano-sedimentary terrains.

From the low and marshy coastal area, the land of Cameroon rises into a rain forest plateau. From there the land moves higher into the central Adamawa Plateau, with elevations reaching over 4,000 ft (Figure 2). To the north of Benoue National Park, the land slopes into a savanna plain that extends to the shores of Lake Chad. In the far southwest Cameroon is mountainous. 

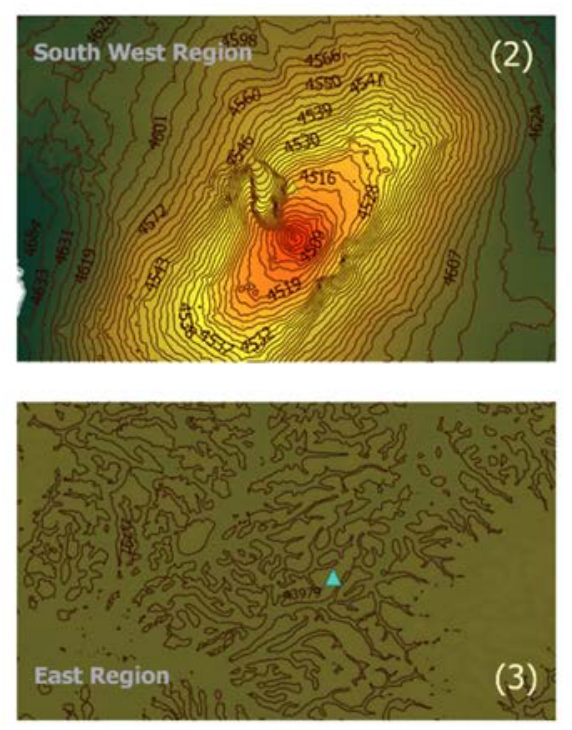

(1) Overview o Cameroon Topography Distribution (2) Highest Altitude Zones (3) Medium Altitude Zones

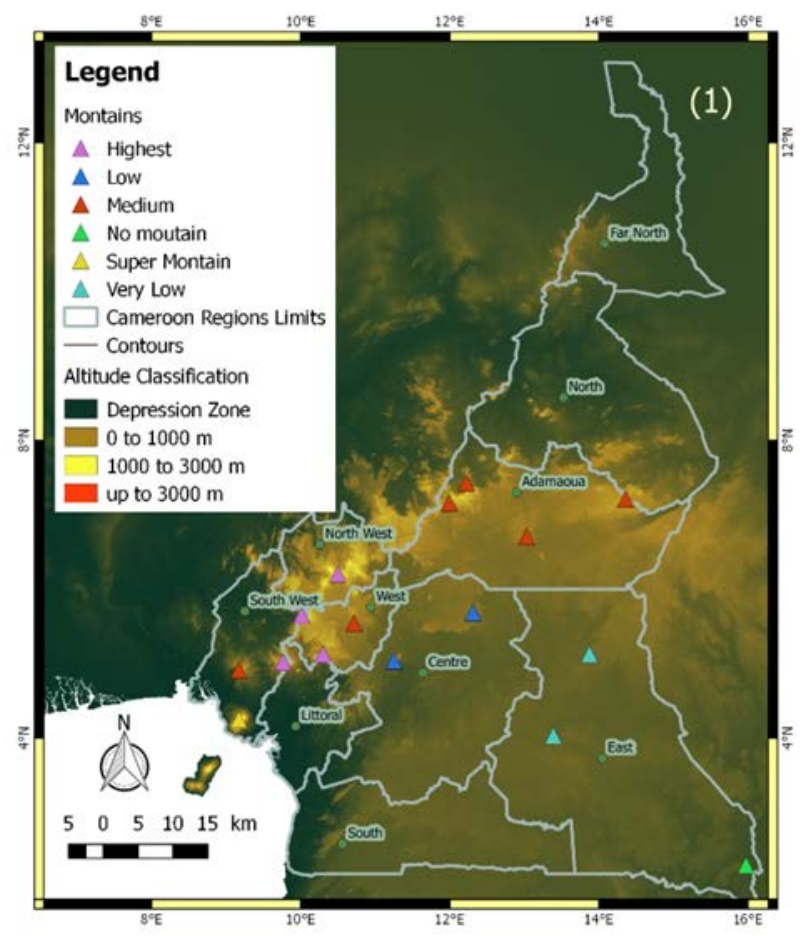

Figure 2. Topographic distribution map of Cameroon

Source: World Resources Institute, 2014

The western part of Cameroon exhibits an irregular chain of mountains, hills, and plateaus that extends from Mount Cameroon almost to Lake Chad at the northern tip of the country. This region includes the Bamenda, Bamiléké, and Mambilla highlands. It also contains some of the country's most fertile soils, notably the rich volcanic soils around Mt. Cameroon. Mt Cameroon (an active volcano), sits on the edge of the Gulf of Guinea, and is the highest point in Central Africa, as well as in Cameroon, at 13,353 ft. (4,070 m). This area of tropical forest has been categorized by the World Wildlife Fund as the Cameroonian Highlands forests ecoregion with Mount Cameroon considered separately because as an active volcano it has a distinct environment from the other mountains. The East region is characterized by a low mountainous relief. Cameroon's lowest point is the Atlantic Ocean $(0 \mathrm{~m})$.

The climate varies with terrain, from tropical along the coast to semiarid and hot in the north. Exceedingly hot and humid, the coastal belt includes some of the wettest places on earth. For example, Debundscha, at the base of Mt. Cameroon, has an average annual rainfall of 10,300 millimetres (NCDC, 2015). The country has four patterns of drainage. In the south, the principal rivers flow southwestward or westward directly to the Gulf of Guinea the Wouri, and lesser Dibamba, Bimbia and Mungo to the Cameroon estuary near Douala; Sanaga, Nyong, and Ntem further south along the coast; Akwayafe and Manyu, and the lesser Ndian and Meme in the north of coast (Gabche and Folack, 1997). The Dja and Kadeï, however, drain southeastward into the Congo River. In northern Cameroon, the Benoué River (Benue) runs north and west, eventually into the Niger, while the Logone River flows northward into Lake Chad. Some of the borders of Cameroon follow rivers, including the Aïna, Akwayafe, and Ntem or Campo.

\section{Brief Description of the Study Area}

The study was undertaken in the East Region of Cameroon (Figure 3).

The East Region of Cameroon has been selected for this study because of the following reasons:

$\checkmark$ It is the largest region in Cameroon in terms of surface area and host the highest number of gold mining sites.

$\checkmark$ It is densely populated by the indigenous pygmies (BAKA), who are a vulnerable group and the most affected by this activity.

$\checkmark$ The reduction and deterioration of agricultural lands due to mining activities in the region.

$\checkmark$ The poverty of the mining communities due to the damaging of various environmental components (soil, water, air and vegetation) during mining operation in the region.

The East Region occupies the south-eastern portion of the Republic of Cameroon (Figure 3). It is bordered to the east by the Central African Republic, to the south by Congo, to the north by the Adamawa Region, and to 


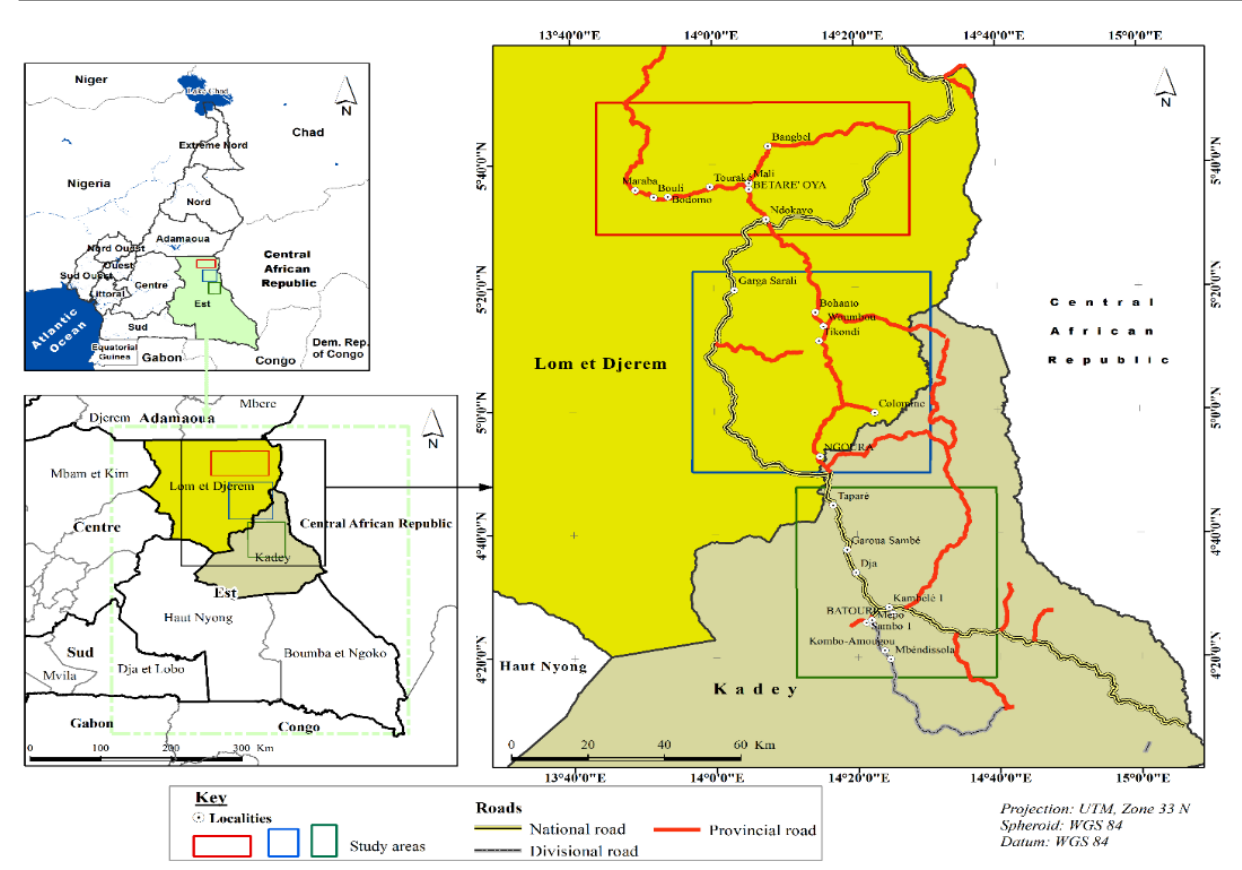

Figure 3. Study area

Source: World Resources Institute, 2014

Table 1. Divisions of the study area

\begin{tabular}{lccc}
\hline & \multicolumn{2}{c}{ DEPARTMENTS } \\
\cline { 2 - 4 } & LOM ET DJEREM & KADEY \\
\hline Districts & Bétaré-Oya & Ngoura & Batouri \\
\hline Total population & 41,173 & 34,489 & 67,007 \\
\hline Total area $\left(\mathrm{Km}^{2}\right)$ & 12,600 & 7,000 & 5,786 \\
\hline Source: $($ BUCREP: 3ème RGPH 2010$)$ & & &
\end{tabular}

Source: (BUCREP: 3ème RGPH 2010)

the west by the Centre and South Regions. With $109,011 \mathrm{~km}^{2}$ of territory, it is the largest region in the nation as well as the most sparsely populated. Historically, the peoples of the East have been settled in Cameroonian territory for longer than any other of the country's many ethnic groups, the first inhabitants being the Baka (or Babinga) pygmies. The East Region has very little industry, its main commerce consisting of logging, timber, and mining. Instead, the bulk of its inhabitants are subsistence farmers. The region is thus of little political import and is often ignored by Cameroonian politicians. This coupled with the low level of development in the province have led to its being dubbed "the forgotten region".

As a consequence, the main viable livelihood opportunity and preferred choice is Artisanal Gold Mining (AGM), the output from which is thought to have a high value to volume ratio. The survey was undertaken in three major mining districts namely: (i) Bétaré-Oya, (ii) Ngoura/Colomine and (iii) Batouri (Figure 3). So, the study covered all gold mining sites (actives and abandoned) areas near the three major mining districts. The sites are accessible via tracks and forest roads.

The Eastern region of Cameroon has four administrative departments / Divisions (Figure 3): Lom and Djerem, Kadey, Upper Nyong and, Boumba and Ngoko. Its headquarters is Bertoua. The study area covers two of these four departments, namely Lom and Djerem for the Bétaré-Oya and Ngoura districts, and Kadey for Batouri district (Table 1). The study area is located between latitudes $4^{\circ} 15^{\prime} 0^{\prime \prime} \mathrm{N}$ and $6^{\circ} 0^{\prime} 0^{\prime \prime} \mathrm{N}$ and longitudes $13^{\circ} 40^{\prime} 0^{\prime \prime} \mathrm{E}$ and $14^{\circ} 40^{\prime} 0^{\prime \prime} \mathrm{E}$. It has a total area of about $9914 \mathrm{~km}^{2}$ (Figure 3).

\section{CONCEPTUAL FRAMEWORK AND LITERATURE REVIEW}

\section{Conceptual Framework}

The conceptual issues for this study are based on Human-Environment Interaction Model (Figure 4) and Distance Decay Model (Figure 5) as discussed below. 


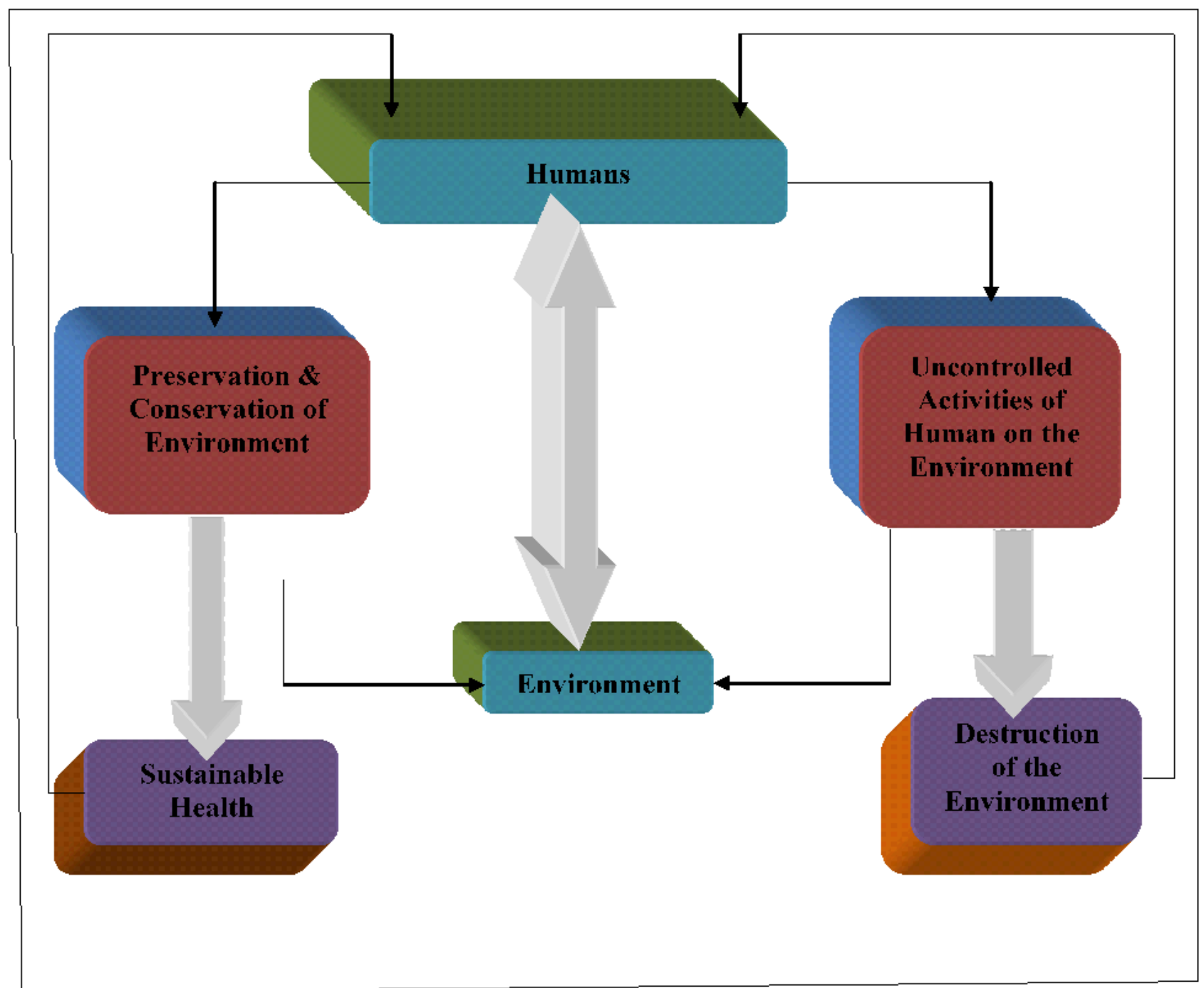

Figure 4. Humans-Environmental Interaction Model

Source: Opara, 2009

\section{Human-Environment Interaction Model}

This concept was built on the idea of human ecology. The ecological relations between humans and their urban environment was founded in Marsh's book published in 1864 (Man and Nature) as revealed by Stallin (2007). Marsh was interested in the active agency of human-nature interactions. In 1916, the term human ecology was used the first time by Huntington, a famous American geographer. Huntington described a new concept explaining the entity of inter-relation between geological contents, the landscape and objects on the earth's surface (Wolanski and Siniarska, 2005). He analysed human populations and their cultural products on the background of environmental conditions. The main claim of Human Environmental Interactions model relates to the interactions between the human social system and (the "rest" of) the ecosystem. Environment and socio-economic variables are unquestionably interrelated. Poor air quality, contaminated water, exposure to toxic chemicals and some vector borne diseases affected ecosystem as well as human health. The recent legacy of human-environment interaction research began in the 1940s to the mid-20th century. During the 1950s, Julian Steward developed the concept of "cultural ecology" wherein he was interested in determining how culture is affected, through land use, by the environment (Opara, 2009).

From the model, the human-environmental interaction model described human in relationship with their environment. The model portrays a system of dependency of human on its and the impact of its attitude and activities on the same environment. These reciprocal relationship deals with two-way process in which environment influences human behaviours and human beings affect environment (Figure 4).

According to the model, environment has both nourishing as well as destructive effect on human beings. Humans being can either choose to protect or destroy their own environment through his/her actions. The resultant of this action is either total destruction or sustainability of the environment. It also revealed the fact that either humans choose to destroy or protect their environment; the repercussion of their choice goes back to them. 


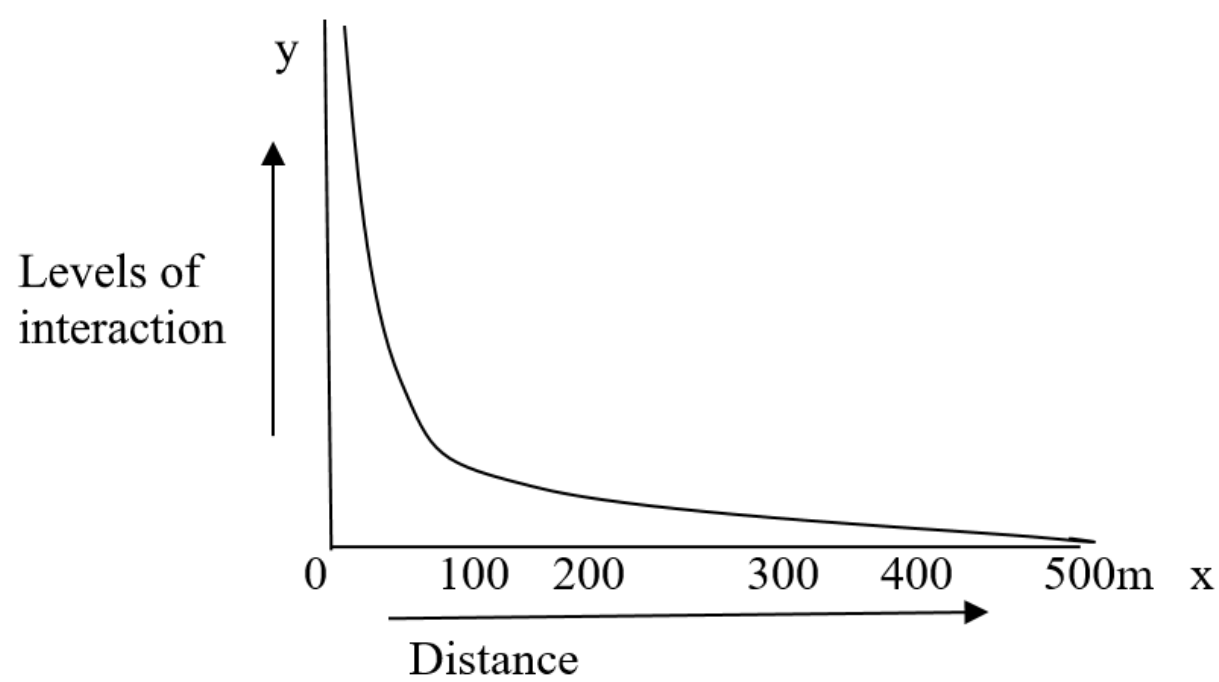

Figure 5. Distance decay curve showing decreasing effect of active mining sites as the distance increases Source: Tobler, 1970

\section{Application of the Model to the Study}

The people's health is at risk when gold mining is not properly monitored. The human-environmental interaction model in this study can help individuals to understand the interaction between resources (natural) and environment, which can be adopted in promoting rural areas for the residents to better understand how they can interact positively with their environment through adequate monitoring and management of gold pit for sustainable healthy environment which will in turn bring about economic development of the area since it is believed that health is wealth. Therefore, it is the prime responsibility of human beings to maintain the environment in trim condition, its destruction means destruction of human life.

\section{Distance Decay Model}

In all aspects, lives are influenced by the friction of distance. This implies that distance has a retarding effect on human interaction because there are increasing penalties in time and cost associated with longer distance. The term friction of distance describes the force that creates distance decay. Distance decay is a geographical term which describes the effect of distance on cultural or spatial interactions. Once the distance is outside of the two locales' activity space, their interactions begin to decrease. Distance decay refers to the decrease or loss of similarity between two observations as the distance between them increases. Tobler (1970), summarized the concept of distance decay to developed the first law of geography, states that "All things are related, but near things are more related than far things".

The underlying assumptions are analogous to the physics theory of gravity. Just as two objects in space exert a stronger gravitational pull on each other as they increase in size and move closer to each other, two places are expected to have a stronger level of interaction as the distance between them decreases.

\section{Application of the Model to the Study}

This model is adopted to determine the effect of gold mining on the socio-economic variables. As the volume of gold mining activities increases, the impacts of that gold mining activities on the health of the nearby residents' increases as well. Likewise, the impact of nearby gold mining activities is assumed to be greater on human health than the impact of more distant gold mining activities, "All things are related, but near things are more related than far things" (Tobler, 1970).

Distance decay is graphically represented by a curving line that swoops concavely downward as distance along the $\mathrm{x}$-axis increases (Figure 5). As you move away from the active mining sites the effects are not as severely affected as those who are closer to the active mining sites. The residents located less than 200 meters from the active mining sites are most likely affected by the mining activities. It is mathematically expressed as

where $I=$ interaction and $d=$ distance.

$$
I=1 / d^{2}
$$




\section{LITERATURE REVIEW}

Environment as used in this study has three components namely, the sum total of external conditions in which organisms exist; the organisms themselves including the floral and faunal community; and the physical surroundings such as landforms. According to Pegg (2003), "Large-scale resource extraction projects can have disastrous local and regional impacts, including toxic contamination of ground and surface water, air pollution, soil degradation, and loss of critical natural ecosystems and biodiversity".

The three stages of mineral development, viz exploration, mining and processing, have caused different types of environmental damages, which include ecological disturbance, destruction of natural flora and fauna; pollution of air, land and water; instability of soil and rock masses; landscape degradation and radiation hazards. The environmental damage has in turn resulted in waste of arable land, as well as economic crops and trees (Adekoya, 2003; Ajakaiye, 1985).

Mining, quarrying, dredging, drilling and extraction from wells are all activities that have a marked impact on the landscape and environment. Directly linked to these activities are problems concerned with the disposal of waste products. Smelting and refining of the ore also constitute serious environmental problems (Muezzinoglu, 2000 and 2003; Duraiappah, 1998; McMahon, 2001; Chachange, 1995).

Mining activities generate vast amounts of waste in the form of overburden, waste rock, and tailings, which may be stored at the surface or deposited in nearby water bodies. Mine tailings have the potential to pollute local watercourses through physical erosion, acidification, thiosalt contamination, and the release of heavy metals or traces of processing chemicals (Sondergaard et al., 2011; Nodem, 2016). The controversial practice of using lakes or fjords for tailings disposal, such as at Maarmorilik in Western Greenland, may result in long-term contamination of these environments (Sondergaard et al., 2011).

Vegetation in form of natural forest or crop plantation is usually the first "casualty" to suffer total or partial destruction or degradation during the exploration and exploitation of minerals in a locality. The vegetation damage is more extensive at the time of mine development and mining operations and is more expensive when crop plantation is affected (Pegg, 2003). Another adverse effect of mineral extraction and processing activities, which may not be immediately felt, is the disturbance of the ecosystem with possible adverse consequences on the floral and faunal community in general. For example, the deforestation of an area during the mine development may cause the elimination of some plants and the exodus from the affected area of some animals that feed on such plants or depend on them for cover. Similarly, the noise generated in the course of blasting, quarrying and crushing can also scare off part of the fauna in a mining locality (Gellert et al., 2003; Pegg, 2003).

Mineral exploitation generally has resulted in the destruction of the scenic landscape which is replaced by unsightly large irregular holes and heaps of debris produced generally by the opencast method of mining (Brooks, 1974). The alteration of the landscape almost invariably creates a problem of erosion in the mining localities with the result that most of the opencast pits are filled with water (Brooks, 1974). Mining operations normally upset the equilibrium in the geological environment, which may trigger off certain geological hazards such as landslide, subsidence, flooding, erosion and tremors with accompanying secondary effects (Aigbedion, 2005; Adekoya, 2003; Gellert et al., 2003; Pegg, 2003).

Some socio-environmental problems are sometimes created as a result of certain peculiarity of the mineral industry. Since minerals are exhaustible and non-renewable commodities, the life of a mine and consequently, the mining activities in a place are limited. The stoppage of mining activities imposed by depletion of the available reserves often leads to migration of people from the mining areas to other places. This may result in the formation of "ghost towns", which are abandoned towns that were previous bubbling mining communities (Adekoya, 2003; Brooks, 1974).

Mining is certainly among the activities which raise numerous environmental degradation concerns, enhanced by continuous demand for new exploitation areas (Jasna Petrić et al; 2011). Drebenstedt (2008) says that surface mining has a greater environmental impact than underground mining. Thus, surface mining operations disturb the surface more seriously (Onuoha, 2008; Jimoh, 2006; Coe et al., 2001, Muezzinoglu, 2003, Traoré, 2015.)

Available literature examines the impact of mining on the health of both mine workers and the people within the surrounding communities of the mines. According to Stephens and Ahern (2001), mining remains one of the most perilous occupations in the world, both in terms of short term injuries and fatalities. Mining is also responsible for long term impacts such as cancer and respiratory conditions (silicosis, asbestosis and pneumoconiosis). Studies of mining and health by type of mine process are divided into deep and open cast mines. Deep mines produce severe harms for employees in terms of their risks of high blood pressure; heat exhaustion; myocardial infarction and nervous system disorders. Studies of surface mining focus on coal, granite and rock mining and health risks related to dust breathing. In all levels of mining health risks occur with dust exposure (Stephens and Ahern, 2001).

Respiratory impacts are the most studied and problematic of health impacts for mine workers. Injuries have declined in importance but continue to be an important safety issue in mines. Long-term effects include cancers, 
mental health impacts and some proof of impacts on genetic integrity of workers. The heated discussion on the impact of the mining and minerals sector on both worker and community health is polarized. On one hand the industry tends to underscore the supposed benefits of the sector, whilst on the other, community groups and NGOs suggest that the sector is injurious to health and sustainable development (Stephens and Ahern, 2001).

According to one study carried out in Kenya in 2002, the major causes of health hazards among miners were inhalation of large amounts of siliceous dust, careless handling of mercury during gold panning and $\mathrm{Au} / \mathrm{Hg}$ amalgam processing, existence of water logged pits and trenches, and large miners sharing poor quality air in the mines (Jason et al., 2002). Myriam and Christophe in 2011 through tools and processes description identified a number of safety hazards in an artisanal mine in the Copperbelt Province of Katanga in five (5) different work places - Digger-craftsman, Crusher, Washer, Loader and Hand-made furnace worker. Some of them include siliceous dust particles in air, working in mud and slurry, working in dark underground galleries, poor ventilation, exposure to high temperatures, working in bad positions, permanent noise and lack of use of personal protection equipment (Myriam and Christopher, 2011).

Although there are risks associated with the extraction of gold, in the context of ASM the predominant concern is in relation to exposure to the mercury that is used in winning the gold from the extracted ore. In the 1980's a modern "gold rush" began in developing countries and millions of people have become artisanal miners, despite these risks. In the interim at least 2000 tonnes of mercury have been released into the environment (Malm, 1998), and this new "gold rush" is reflected in the world-wide demand for gold, which is currently $44 \%$ above the total annual production of the world's gold mines (UNIDO, 2001).

Studies on the health impacts of AGM have not been extensively carried out in Cameroon. However, one study on Environmental and Socio-economic Assessment of Artisanal Gold Mine Field in Bétaré-Oya reported that most miners appeared physically well fit, though they reported backaches, muscle aches, hernias, respiratory conditions, and high prevalence of malaria (Tetsopgang et al., 2007). Borralho, in his report specified the most common types of respiratory conditions: silicosis, silicotuberculosis, pulmonary TB, obstructive airways disease, occupational asthma, oral and/or nasal cavity erosions (Borralho, 2013).

\section{Artisanal Gold Mining}

In this work artisanal gold mining (AGM) is referred to as small-scale mining. The term 'small-scale mining' is the subject of great debate in the sub-region. Generally, the main criteria commonly used in the attempts to define the precise content of this expression are:

- The physical size of the deposit and the continuity or not of mining activities.

- The organizational structure of the activity and the management system.

- The importance of investment required and turnover generated.

- The number and level of qualifications of the workers involved in the production unit.

- The kind of equipment, degree of mechanization and the level of technology used.

After several seminars on the promotion of small-scale mining held by some experts in 1990 the following definition of small-scale mining was adopted: mining operations which are easily controlled technologically and financially by under-equipped populations with limited means and exploited as individuals, families, associations or cooperatives (Seydou, 2002). This is the definition adopted in this research.

AGM is a considerable and growing business in many developing countries. AGM is often informal and associated with conflict, corruption, civil strife and rapid degradation of the environment. Yet if soundly managed, AGM as other artisanal mining activities has the potential to contribute significantly to social and economic development, and offers an opportunity for a sustainable alleviation of poverty in some developing countries like Cameroon.

\section{Artisanal Gold Mining in Eastern Cameroon}

AGM has been taking place in East Cameroon since 1934 (Gazel et al., 1954). The current annual production of gold in Cameroon is estimated at 1,500 kg (George, 2009) but no reliable historical gold production data exist. Generally, there are two types of mining exploitation in Eastern Cameroon: the artisanal small-scale mining (ASM) and the semi-mechanized mining. The mining process is basically the same for both but only differs in their degrees of mechanization. Both forms of exploitation are classified under the artisanal sector as artisanal gold mining (AGM) in Cameroon.

AGM in Eastern Cameroon consists of five (5) steps as in Figure 6. 


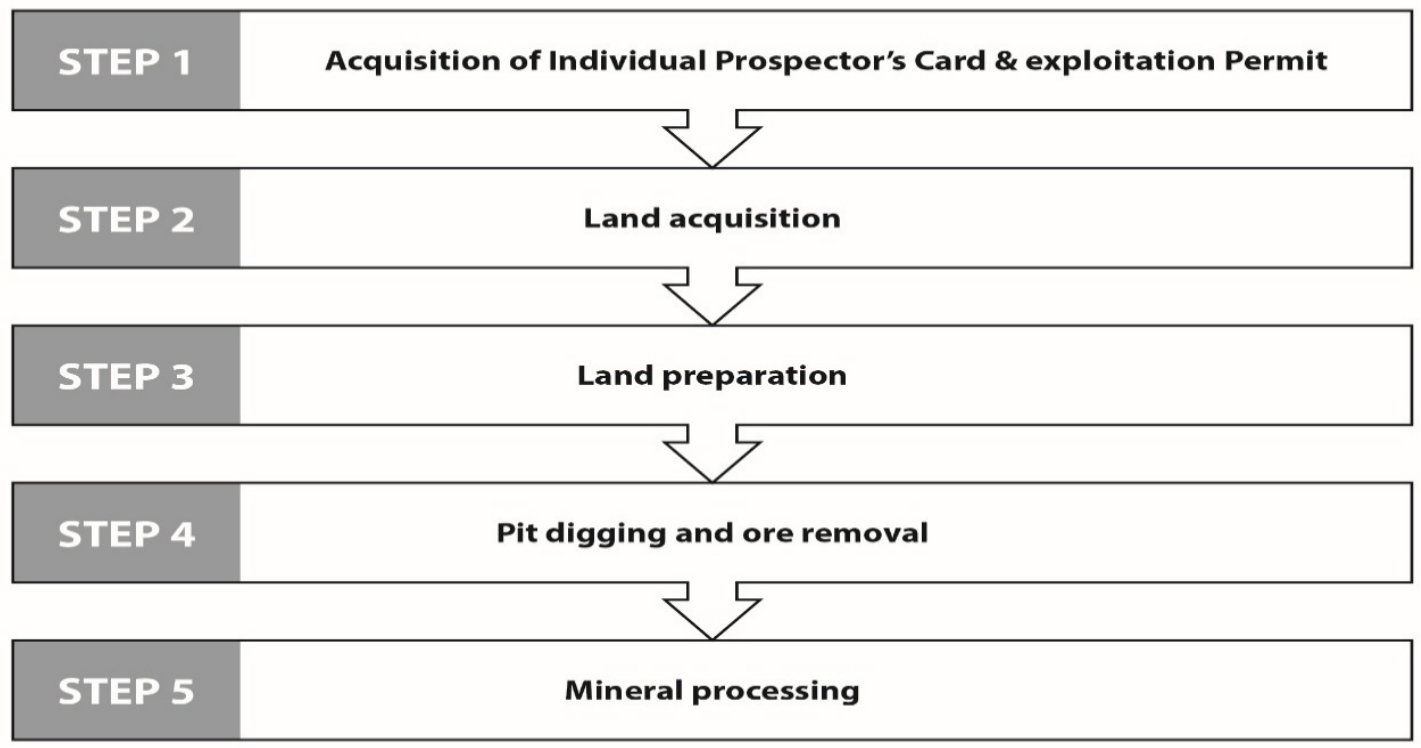

Figure 6. Steps involved in the process of gold mining in eastern Cameroon Source: Cameroon mining guide, 2014

\section{MATERIALS AND METHODS}

This study employed survey research design through the use of primary data which covered a period of over eight (08) months from the 24th of June, 2016 to the 14th of February, 2017. A multistage sampling technique was used to select sample size of 440 proportionally across the three units that make up the study area. The units were subsequently classified into localities after which questionnaires were administered to the enumerated buildings systematically chosen along the streets in each ward. Credence was given to every $10^{\text {th }}$ building in each street. The instrument of investigation included questionnaire, in-depth interview and focus group discussion. Table 2 shows the selected areas in each unit, their population size and the number of questionnaires administered in each of the wards.

The target population of study corresponds to the Bétaré-Oya, Ngoura and Batouri gold districts. These three districts have been the main regions for AGM in Cameroon for over 70 years. The three districts visited have common aspects as well as points of divergence. The district of Ngoura is characterized by its difficult access by car (coming from Bétaré-Oya). The access road is certainly passable but in poor condition at the time we borrowed it. The other two districts, Bétaré-Oya and Batouri, have access roads that are much more practicable. Almost all mining sites are accessible by motorcycle and by foot (Plate 1). Each time we focused on visiting active sites and abandoned sites. In total, 32 sites were visited.

The target population of study was divided into three main groups: Local administrative authorities, local residents (Miner, Farmer, village chief, other community members, NGOs and CSOs) and medical Cops. Local administrative authorities included the Heads of Divisions (Lom and Djerm and Kadey Divisions), the Heads of Districts (Bétaré-Oya, Ngoura and Batouri), The Heads of Municipalities (Bétaré-Oya, Ngoura and Batouri), the officials of CAPAM (Support and Promotion Framework of Mining Activities in Cameroon), the chiefs of mining companies the Departmental Delegates of Mines Industries and Technological Development and the Departmental Delegates of Environment Nature Protection and Sustainable Development. The local residents were represented by Miners involved in the gold exploitation activity at various workplaces, local chiefs, farmers NGOs, CSOs and the natives (non-miners) living in the mining communities. The medical Cops such as District Health Service officials and Medical Delegates. 
(A) Access to mining site by motorcycle

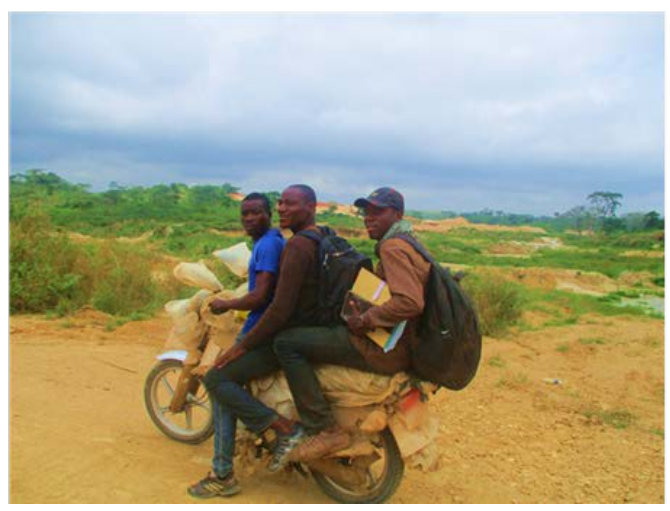

(B) Access to mining site by foot

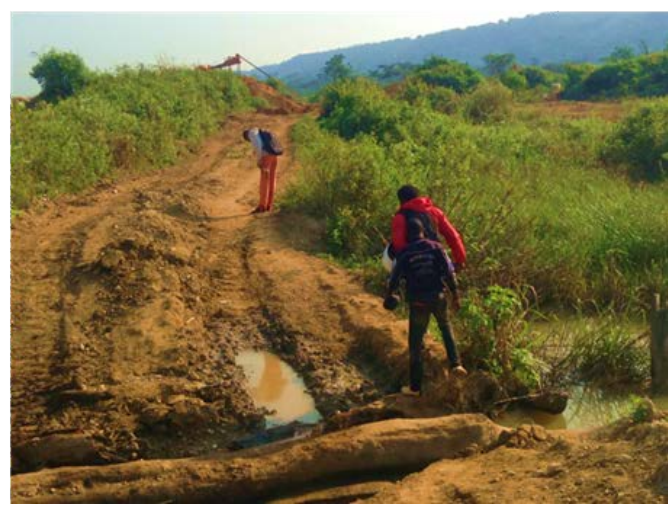

Plate 1. Accessibility to mining site, Eastern Cameroon (Author Fieldwork, 2016)

Table 2. Area and population of the mining districts

\begin{tabular}{lcc}
\hline Districts & Area $\mathbf{( k m}^{\mathbf{2}}$ & Target population \\
\hline Bétaré-Oya & 3,238 & 16,129 \\
\hline Ngoura & 3,715 & 11,496 \\
\hline Batouri & 2,961 & 13,249 \\
\hline Total & 9,914 & 40,874 \\
\hline
\end{tabular}

Source: (BUCREP: 3ème RGPH 2010)

\section{Sampling Procedures and Techniques}

\section{Sample Size Determination Process}

Terrain surveys had held within three (03) Districts/Subdivisions where mining activities are predominantly located in Eastern Cameroon (Bétaré-Oya, Ngoura and Batouri). The villages covered (24 villages) have been determined depending on the presence of exploited or abandoned mining sites.

The sample size has been determined using the standard scientific formula given by Bryman (2012). This formula is used to estimate the smallest possible categorical sample size since the target population of study area is above 10000 .

where

$$
n=Z \alpha^{2} \times P \cdot Q / d^{2}
$$

$n$ : Design sample size where $(N>10000)$

$Z \alpha$ : Standard normal deviation usually set at 1.96 which corresponds to $95 \%$ confidence level

$P$ : Proportion of the target population estimated to have particular characteristics that is equal to $50 \%$

$Q=1-P=(1-0.5)$

$d$ : Permitted error (5\% if the confidence level is $95 \%) ; 0.05$

$$
n=\frac{(1.96)^{2} \times 0.5 \times 0.5}{(0.05)^{2}} \quad n=384.16 \cong 385
$$

To maintain the same measure of confidence (95\%), Miller and Brewer (2003) propose the following formula and this formula will also be applied to retain one that will give the best accuracy. where

(i) Sample size: $n=\frac{N}{1+N(\propto)^{2}}$

$n$ : Design sample size

$N$ : given population size (Bétaré-Oya, Ngoura and Batouri, see Table 2).

$\propto:$ Level of significance or margin error $(5 \%)$

$$
n=\frac{40874}{1+40874(0.05)^{2}} \quad n=\frac{40874}{1+40874 \times 0.0025} \quad n=400
$$

Given that a non-response margin of $10 \%$ will be allowed, then

Thus, the sample size of this study was 440 individuals.

$$
N=n+10 \% n=400+\left(\frac{10}{100}\right) 400=440 .
$$


Table 3. Districts and sample size

\begin{tabular}{lcc}
\hline Districts & Number of questionnaires & Number of covered villages \\
\hline Bétaré-Oya & 100 & 8 \\
\hline Ngoura & 150 & 6 \\
\hline Batouri & 190 & 10 \\
\hline Total & 440 & 24 \\
\hline
\end{tabular}

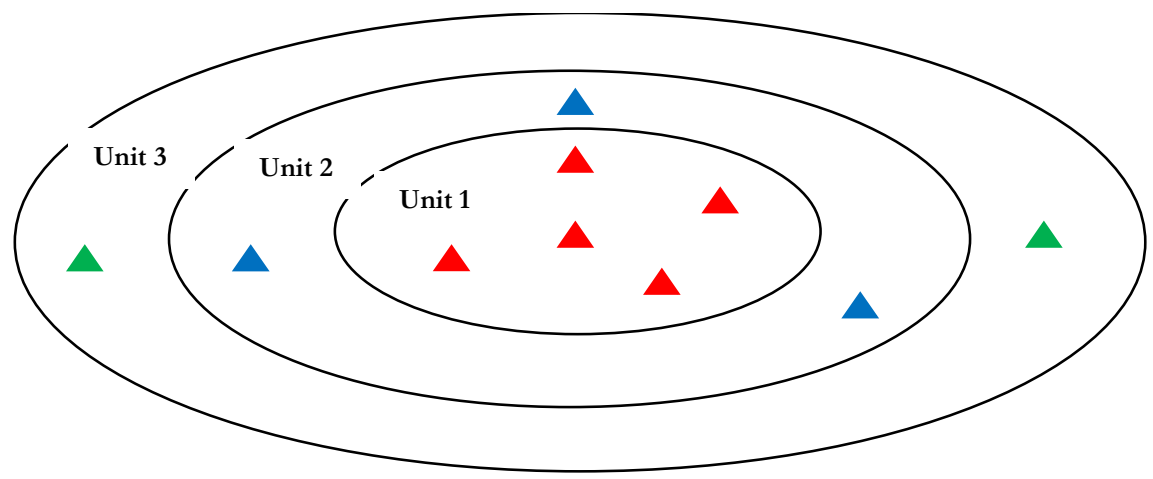

Unit 1: villages labelled in red signify active mining sites,

Unit 2: villages (03) labelled in blue signify immediate adjoining villages of the mining sites,

Unit 3: villages (02) labelled in green signify villages further away from the mining sites.

Figure 7. Spatial distribution model of selected villages

Table 4. Villages and sample size

\begin{tabular}{|c|c|c|c|}
\hline Selected villages & Population & Sample size & Units \\
\hline \multicolumn{4}{|c|}{ BÉTARÉ OYA (100) } \\
\hline Mali & 795 & 17 & \multirow{3}{*}{ Unit 1} \\
\hline Bouli & 1395 & 17 & \\
\hline Bétaré-Oya & 8206 & 16 & \\
\hline Touraké & 791 & 10 & \multirow{3}{*}{ Unit 2} \\
\hline Bangbel & 1110 & 10 & \\
\hline Bodomo & 424 & 10 & \\
\hline Ndokayo & 2757 & 10 & \multirow{2}{*}{ Unit 3} \\
\hline Maraba & 651 & 10 & \\
\hline \multicolumn{4}{|c|}{ NGOURA (150) } \\
\hline Woumbou & 1264 & 37 & \multirow{2}{*}{ Unit 1} \\
\hline Colomine & 3503 & 38 & \\
\hline Bohanto & 777 & 22 & \multirow{2}{*}{ Unit 2} \\
\hline Tikondi & 563 & 23 & \\
\hline Garga Sarali & 2756 & 15 & \multirow{2}{*}{ Unit 3} \\
\hline Ngoura & 2633 & 15 & \\
\hline \multicolumn{4}{|c|}{ BATOURI (190) } \\
\hline Boukarou (Kambélé 3) & 555 & 19 & \multirow{5}{*}{ Unit 1} \\
\hline Taparé & 1333 & 19 & \\
\hline Sambo 1 & 8295 & 19 & \\
\hline Garoua Sambé & 1049 & 19 & \\
\hline Ndombé-Gouaké & 446 & 19 & \\
\hline Kambélé 1 & 651 & 19 & \multirow{3}{*}{ Unit 2} \\
\hline Mepo & 465 & 19 & \\
\hline Kombo-Amougou & 249 & 19 & \\
\hline Dja & 87 & 19 & \multirow{3}{*}{ Unit 3} \\
\hline Mbéndissola & 119 & 19 & \\
\hline & & 440 & \\
\hline
\end{tabular}

Unit 1: villages labelled in red signify active mining sites,

Unit 2: villages (03) labelled in blue signify immediate adjoining villages of the mining sites,

Unit 3: villages (02) labelled in green signify villages further away from the mining sites.

\section{Selection Procedure}

The selection of villages (Table 3), their spatial distribution (Figure 7) and the number of questionnaires administered (Table 4) was carried out after an investigation of the study area; Depending on the extent and evolution of exploitation made possible by a preliminary study (Literature review, observations, and interviews with local Authorities, NGOs and CSOs). 


\section{Spatial Distribution}

The villages were chosen as such in an attempt to assess and evaluate the impacts of the mining activities in the immediate communities where mining is taking place and also the variation of such impacts in communities further away from mining sites. Thus, for better distribution and rational representation of questionnaires administered, $50 \%$ of the questionnaires were allocated to Unit 1, made up of all villages with one or more mining sites (Active and/or Abandoned). $30 \%$ of the questionnaires were allocated to Unit 2, constituting villages closest to Unit 1, and $20 \%$ to Unit 3, composed of villages far away from the mining sites. For the latter unit, the number of villages was set at two (02), representing the control sites.

\section{DATA ANALYSIS METHOD}

Descriptive statistics such as frequencies, percentages, cross-tabulations and charts (Bar charts) were used to analyse the pattern of perception of the impacts of gold mining in the study area. In addition, the interview and the focus group discussion were analysed using thematic approach and the relevant points were reported. Finally, Chi-Square test $\left(\mathrm{X}^{2}\right)$ was used to test for the significant difference in the stated hypothesis (perceived negative effects of gold mining on different socio-economic variables (such as culture, health, education and economy) vary significantly depending on the proximity from the mining areas.

\section{FINDINGS AND DISCUSSION}

\section{Socio-Economic Characteristics of Respondents}

As presented in Table 5, about $87.7 \%$ of respondents were males while $12.3 \%$ were females. It indicates that majority of them are males. This might be as a result of the fact that the study focuses on mining communities. The age of respondents ranged from 15 to 72 with an average of $37.08 \pm 14.77$ years. The dominant age is between $37-54$ years $(47.3 \%)$, followed by $18-36$ Years $(32.1 \%)$, less than 18 years $(10.6 \%)$ and the least being $55-72$ years $(9.9 \%)$. This shows that majority of the sampled respondents fall within working age and are still productive, this might be as a result of their occupation which requires an active age group.

Table 5. Socio-economic characteristics of respondents

\begin{tabular}{|c|c|c|c|}
\hline & & Frequency & Percentage (\%) \\
\hline \multirow{2}{*}{ Sex } & Male & 386 & 87.7 \\
\hline & Female & 54 & 12.3 \\
\hline \multirow{4}{*}{ Age } & $<18$ years & 44 & 10.6 \\
\hline & 18-36 Years & 133 & 32.1 \\
\hline & 37-54 Years & 196 & 47.3 \\
\hline & $55-72$ years & 41 & 9.9 \\
\hline \multirow{4}{*}{ Education } & Primary school & 161 & 39.9 \\
\hline & Secondary school & 113 & 28.0 \\
\hline & Tertiary & 7 & 1.7 \\
\hline & No formal education & 123 & 30.4 \\
\hline \multirow{5}{*}{ Ethnicity groups } & Kako & 139 & 31.6 \\
\hline & Gbaya & 250 & 56.8 \\
\hline & Bamiléké & 7 & 1.6 \\
\hline & Bororo & 33 & 7.5 \\
\hline & Haoussa & 11 & 2.5 \\
\hline \multirow{5}{*}{ Secondary occupation } & Farmer & 89 & 41.0 \\
\hline & Fisherman & 65 & 30.0 \\
\hline & Member of NGO & 2 & 1.0 \\
\hline & Miner & 50 & 23.0 \\
\hline & Trader & 11 & 5.1 \\
\hline \multirow{2}{*}{ Marital status } & Married & 358 & 85.4 \\
\hline & Single & 61 & 14.6 \\
\hline \multirow{4}{*}{ Number of wife/wives } & $1 \mathrm{Wife}$ & 243 & 77.9 \\
\hline & 2 Wives & 60 & 19.2 \\
\hline & 3 Wives & 8 & 2.6 \\
\hline & 4 Wives & 1 & .3 \\
\hline \multirow{6}{*}{ Number of children } & 1-2 Children & 77 & 19.9 \\
\hline & 3-4 Children & 128 & 33.2 \\
\hline & 5-6 Children & 104 & 26.9 \\
\hline & 7-8 Children & 58 & 15.0 \\
\hline & 9-10 Children & 12 & 3.1 \\
\hline & Above 10 Children & 7 & 1.8 \\
\hline
\end{tabular}


Table 6. Effects of mineral exploitation on inhabitants

\begin{tabular}{|c|c|c|c|c|c|}
\hline Variables & & Unit 1 & Unit 2 & Unit 3 & Total \\
\hline \multirow[t]{3}{*}{ Positive impacts } & Construction of houses & $8(44.4 \%)$ & $1(5.6 \%)$ & $0(0.0 \%)$ & $9(50.0 \%)$ \\
\hline & Infrastructural development & $8(44.4 \%)$ & $1(5.6 \%)$ & $0(0.0 \%)$ & $9(50.0 \%)$ \\
\hline & Changes in the colour and taste of water & $10(41.7 \%)$ & $1(4.2 \%)$ & $0(0.0 \%)$ & $11(45.8 \%)$ \\
\hline \multirow[t]{3}{*}{ Negative impacts } & Removal of buried people due to mining & $3(12.5 \%)$ & $1(4.2 \%)$ & $0(0.0 \%)$ & $4(16.7 \%)$ \\
\hline & Dryness of rivers & $3(12.5 \%)$ & $1(4.2 \%)$ & $0(0.0 \%)$ & $4(16.7 \%)$ \\
\hline & Reductions in the species of animals & $5(20.8 \%)$ & $0(0.0 \%)$ & $0(0.0 \%)$ & $5(20.8 \%)$ \\
\hline
\end{tabular}

Unit 1: villages labelled in red signify active mining sites,

Unit 2: villages (03) labelled in blue signify immediate adjoining villages of the mining sites,

Unit 3: villages (02) labelled in green signify villages further away from the mining sites.

Source: Author Fieldwork, 2017

Also, majority of respondents who were influenced by gold mining activities had attained a primary level of education, comprising $39.9 \%$, about $30.4 \%$ of them did not complete any formal education, while $28.0 \%$ completed secondary school, $1.7 \%$ attended a university or other tertiary school. Education levels in the study area on average is very low, this indicates that mining does not required high level of education. It was discovered that majority of them were married (85.4\%) and singles accounted for $14.6 \%$ (Table 5). The number of wife/wives ranged from 1 to 4 , with an average number of 1 . Majority of them had 1 wife $(77.9 \%)$, followed by those with two wives (19.2\%), 3 wives $(2.6 \%)$ and 4 wives $(0.3 \%)$ respectively. The number of children ranged from 1 to 15 , with an average number of 4 . About $33.2 \%$ of respondents had 3-4 children, followed by those with 5-6 children (26.9\%), 1-2 children (19.9\%), 7-8 children (15.0\%) and the least being 10 children and above (1.8\%). These imply that there are more people who get married to a wife with 3-4 children in the study area.

\section{Impact of Gold Mining Exploitation on Inhabitants}

Mining exploitations have impacted inhabitants of study area positively and negatively. The respondents in villages within the active mining sites agreed that the positive impacts of mining exploitations are construction of houses and infrastructural development with $44.4 \%$ each. However, about $41.7 \%$ in the same area also claimed that mining exploitations have brought about changes in the colour and taste of their water, reductions in the species of animals $(20.8 \%)$, dryness of rivers $(12.5 \%)$ and buried people have been removed during mining activities $(12.5 \%)$. These results imply that villages within the active mining sites benefited significantly from mining activities and at the same time they are more impacted adversely as a result of mining exploitations especially in the domain of water quality as in they had been experiencing changes in the colour and taste of drinkable water (Table 6).

The Divisional delegate of mines (MINMIDT) from Kadey division at Batouri, reported that:

"The positive impacts of gold mining in my locality include employment of youths and improvement in the local economy. At the local level, the income of the inhabitants has increased as a result of the increase in the price of Gold in the market. Apart from these, I am aware of the projects developed for the sustainable management for the environment in the mining sector in my locality. Some of these projects are: Promess project conducted by FODER (NGO). Other projects were conducted by CEPEDIC (NGO) and ADD-Clairnet (NGO).

However, the negative social impacts include the following: school dropout, prostitution, overexploitation of women, low education of young girl and low agriculture activity, livestock, fishery, hunting and commerce, lack of development in terms of social infrastructure and communication development. Above all, there has been an inverse relationship between mining and development because poverty level is too high. It is surprising that the mining companies have not rehabilitated any site after mineral exploitation in my community" $(02 / 02 / 2017)$.

\section{Impact of Gold Mining Exploitation on Human Health}

According to Table 7, malaria, diarrhoea and typhoid fever were the main threats to public health in the localities. Out of these diseases, about $44.9 \%$ confirmed that they were infected by malaria, followed by typhoid fever $(29.0 \%)$ and the least being diarrhoea with $26.1 \%$. These results show that gold mining has promoted the spread and growth of these diseases and it could be due to the fact that the miners are leaving pits with water which form breeding grounds for mosquitos which in turn bringing malaria across the localities. One study on Environmental and Socio-economic Assessment of Artisanal Gold Mine Field in Bétaré-Oya reported that most miners appeared physically well fit, though they reported backaches, muscle aches, hernias, respiratory conditions, and high prevalence of malaria (Tetsopgang et al., 2007). 
Table 7. The most common diseases in the localities

\begin{tabular}{llcccc}
\hline Variables & & Unit 1 & Unit 2 & Unit 3 & Total \\
\hline Most common diseases & Malaria & $217(24.1 \%)$ & $116(12.9 \%)$ & $72(8.0 \%)$ & $405(44.9 \%)$ \\
\cline { 2 - 5 } & Diarrhoea & $130(14.4 \%)$ & $79(8.8 \%)$ & $26(2.9 \%)$ & $235(26.1 \%)$ \\
\cline { 2 - 5 } Disease that causes more damage in the localities & Typhoid fever & $117(13.0 \%)$ & $83(9.2 \%)$ & $62(6.9 \%)$ & $262(29.0 \%)$ \\
\cline { 2 - 5 } & Malaria & $168(38.2 \%)$ & $121(27.5 \%)$ & $70(15.9 \%)$ & $359(81.6 \%)$ \\
\cline { 2 - 5 } & Diarrhoea & $41(9.3 \%)$ & $11(2.5 \%)$ & $7(1.6 \%)$ & $59(13.4 \%)$ \\
\cline { 2 - 5 } & Typhoid fever & $11(2.5 \%)$ & $0(0.0 \%)$ & $11(2.5 \%)$ & $22(5.0 \%)$ \\
\hline
\end{tabular}

Unit 1: villages labelled in red signify active mining sites,

Unit 2: villages (03) labelled in blue signify immediate adjoining villages of the mining sites,

Unit 3: villages (02) labelled in green signify villages further away from the mining sites.

Source: Author Analysis, 2017

Table 8. Effects of gold exploitation on education

\begin{tabular}{llcccc}
\hline & \multicolumn{1}{c}{ Variables } & Unit 1 & Unit 2 & Unit 3 & Total \\
\hline \multirow{2}{*}{ Positive effects } & Financing education & $12(37.5 \%)$ & $0(0.0 \%)$ & $0(0.0 \%)$ & $12(37.5 \%)$ \\
\cline { 2 - 5 } & Economic reinforcement & $16(50.0 \%)$ & $0(0.0 \%)$ & $4(12.5 \%)$ & $20(62.5 \%)$ \\
\hline \multirow{3}{*}{ Negative effects } & Abandoning of school for mining & $54(75.0 \%)$ & $0(0.0 \%)$ & $0(0.0 \%)$ & $54(75.0 \%)$ \\
\cline { 2 - 6 } & Buildings devastation & $0(0.0 \%)$ & $0(0.0 \%)$ & $1(1.4 \%)$ & $1(1.4 \%)$ \\
\cline { 2 - 6 } & Cost of education & $0(0.0 \%)$ & $0(0.0 \%)$ & $4(5.6 \%)$ & $4(5.6 \%)$ \\
\cline { 2 - 6 } & No portable water within the school environment & $2(2.8 \%)$ & $0(0.0 \%)$ & $0(0.0 \%)$ & $2(2.8 \%)$ \\
\cline { 2 - 5 } & Negligence by parents & $1(1.4 \%)$ & $10(13.9 \%)$ & $0(0.0 \%)$ & $11(15.3 \%)$ \\
\hline
\end{tabular}

Unit 1: villages labelled in red signify active mining sites,

Unit 2: villages (03) labelled in blue signify immediate adjoining villages of the mining sites,

Unit 3: villages (02) labelled in green signify villages further away from the mining sites.

Source: Author Analysis, 2017

In addition, majority submitted that malaria was the number one type of disease that has caused more damage in the localities (81.6\%). Between 38.2\%, 27.5\% and 15.0\% respectively in both groups also claimed that malaria was the number one disease that caused more damage in their localities. Regional differences were more profound due to the fact that those living and working in unit 2 and unit 3 were least exposed to malaria compare to inhabitants of unit 1. Similarly, those in unit 2 never had typhoid fever $(0.0 \%)$ unlike those in unit $1(2.5 \%)$ and unit $3(2.5 \%)$ respectively. Thus, people living within the active mining sites (Unit 1) are the most affected by malaria, diarrhoea and typhoid fever (Table 7).

Focus group discussion conducted at Bétaré-Oya district, Mali village, Lom et Djerem division reported that:

"Malaria is among the main threats to human's health in the villages that are located within the active mining sites. Gold mining activities have promoted the spread and expansion of malaria because there are several pits with dirty water, which in turn form breeding fertile grounds for the mosquitos and other related insects" (30/08/2016).

\section{Impact of Gold Mining Exploitation on Education}

Mining exploitations have impacted educational sector in the study area positively and negatively. The respondents in villages within the active mining sites claimed that the positive impacts of mining exploitations are economic reinforcement $(50.0 \%)$ and financial supports for education (34.4\%). However, about $75.0 \%$ in this area also pointed out that mining activity has successfully enabled their children to abandon school for mining, shortage of water in the school premises $(2.8 \%)$ and negligence of education by parents $(1.2 \%)$. Cost of education $(5.6 \%)$ and buildings devastation (1.4\%) were reported by the respondents from villages far away from the active mining sites (unit 3). These results imply that villages in the active mining sites benefited more from mining activities in terms of educational development and at the same time they are more impacted negatively as a result of mining exploitations especially in the area of student being abandoning schools for mining activities (Table 8).

Focus group discussion conducted at Bétaré-Oya district, Mali village, Lom et Djerem division reported that:

"The main effect of gold mining activities on educational development being that our children are abandoning schools for mining because of their quest to get rich quickly" (30/08/2016).

\section{Impact of Gold Mining Exploitation on Economy}

Inhabitants of unit 1 directly linked the problems facing their economic activities to the following: inadequate arable land for agriculture (33.8\%), Destruction of organism in the soil $(16.9 \%)$, intrusion of animals into the field $(5.3 \%)$ and lack of follow-up $(7.7 \%)$ and stealing of farm produce $(1.4 \%)$ were mainly reported by respondents from unit 2 and destruction of harvest by pest was mainly stated by respondents from unit $3(6.3 \%)$. These suggest 
Table 9. Problems facing economic activities

\begin{tabular}{lcccc}
\hline Perceived problems & Unit 1 & Unit 2 & Unit 3 & Total \\
\hline Lack of follow-up & $9(4.3 \%)$ & $16(7.7 \%)$ & $0(0.0 \%)$ & $25(12.0 \%)$ \\
\hline Intrusion of animals into the field & $11(5.3 \%)$ & $0(0.0 \%)$ & $0(0.0 \%)$ & $11(5.3 \%)$ \\
\hline Destruction of organism in the soil & $35(16.9 \%)$ & $1(0.5 \%)$ & $11(5.3 \%)$ & $31(15.0 \%)$ \\
\hline Inadequate arable land for agriculture & $70(33.8 \%)$ & $19(9.2 \%)$ & $5(2.4 \%)$ & $94(45.4 \%)$ \\
\hline Destruction of harvest by pest & $0(0.0 \%)$ & $11(5.3 \%)$ & $13(6.3 \%)$ & $24(11.6 \%)$ \\
\hline Stealing of farm produce & $2(1.0 \%)$ & $3(1.4 \%)$ & $1(0.5 \%)$ & $6(2.9 \%)$ \\
\hline Total & $127(61.4 \%)$ & $50(24.2 \%)$ & $30(14.5 \%)$ & $207(100.0 \%)$ \\
\hline
\end{tabular}

Unit 1: villages labelled in red signify active mining sites,

Unit 2: villages (03) labelled in blue signify immediate adjoining villages of the mining sites,

Unit 3: villages (02) labelled in green signify villages further away from the mining sites.

Source: Author Analysis, 2017

Table 10. Effects of mining activities on water quality

\begin{tabular}{llccc}
\hline Perceived effects & Unit 1 & Unit 2 & Unit 3 & Total \\
\hline River course destroyed & $21(25.3 \%)$ & $3(3.6 \%)$ & $0(0.0 \%)$ & $16(28.9 \%)$ \\
\hline No fish in the river because of pollution & $10(12.0 \%)$ & $0(0.0 \%)$ & $0(0.0 \%)$ & $10(12.0 \%)$ \\
\hline Changes in the taste and colour of water & $36(43.4 \%)$ & $13(15.7 \%)$ & $0(0.0 \%)$ & $45(59.1 \%)$ \\
\hline Total & $67(80.7 \%)$ & $18(19.3 \%)$ & $1(1.2 \%)$ & $83(100.0 \%)$ \\
\hline
\end{tabular}

Total

Unit 2: villages (03) labelled in blue signify immediate adjoining villages of the mining sites,

Unit 3: villages (02) labelled in green signify villages further away from the mining sites.

Source: Author Analysis, 2017

that there are several problems facing economic activities in the study area but lack of follow-up was the main problem and inadequate arable land for agriculture (Table 9).

The mayor of Bétaré-Oya municipality stated that:

"The environmental impacts of gold mining on economy in my locality include the following: deforestation, silting of river beds, morbid impacts on aquatic ecosystems, pollution of toxic substances in the environment, destruction of arable lands, evaporation of toxic products like heavy metals, mercury, cyanide, lead, encroachment of mine sites on lands such as agriculture, pasture, fisheries and hunting and hunting and fertility for farming has been reduced drastically" (30/11/2016).

\section{Impact of Gold Mining Exploitation on Water Quality}

Mining exploitations have impacted the quality of water in the study area adversely. Respondents in villages across the study area agreed that mining exploitations have brought changes in the colour and taste of their drinking water $(59.1 \%)$, followed by destruction of the course of rivers $(28.9 \%)$ and no fish in the river again because of pollution $(12.0 \%)$. These results imply that villages around active mining sites are more impacted severely as a result of mining exploitations principally in the area of water quality as in they had been experiencing changes in the colour and taste of potable water (Table 10).

Focus group discussion conducted at Bétaré-Oya district, Mali village, Lom et Djerem division reported that:

"Water pollution is the main problem when it comes to the effect of gold mining on the quality of water. Gold mining activities are making our rivers to disappear. Water that used to be drinkable some years back no longer suitable for human consumption. In some villages within the active mining sites, the problem has aggravated to the extent that even drinking, cooking and washing have become major problems" (30/08/2016).

\section{Impact of Gold Mining Exploitation on Livestock Farming}

Inhabitants across the study area correlated the problems facing livestock farming to the following: diseases as a result of mining activities (64.6\%), stealing (31.3\%), lack of market $(2.4 \%)$ and draught $(1.7 \%)$. These imply that there are several problems facing livestock farming in the study area but diseases are the main problem across the study area (Table 11). 
European Journal of Sustainable Development Research, 2(2), 23

Table 11. Problems facing livestock farming

\begin{tabular}{lcccc}
\hline Perceived problems & Unit 1 & Unit 2 & Unit 3 & Total \\
\hline Diseases as a result of mining activities & $112(29.4 \%)$ & $92(22.3 \%)$ & $53(12.9 \%)$ & $266(64.6 \%)$ \\
\hline Theft & $56(13.6 \%)$ & $55(13.3 \%)$ & $18(4.4 \%)$ & $129(31.3 \%)$ \\
\hline Drought / Lack of water & $6(1.5 \%)$ & $0(0.0 \%)$ & $1(0.2 \%)$ & $7(1.7 \%)$ \\
\hline No market & $2(0.5 \%)$ & $0(0.0 \%)$ & $8(1.9 \%)$ & $10(2.4 \%)$ \\
\hline Total & $185(44.9 \%)$ & $147(35.7 \%)$ & $80(19.4 \%)$ & $412(100.0 \%)$ \\
\hline
\end{tabular}

Unit 1: villages labelled in red signify active mining sites,

Unit 2: villages (03) labelled in blue signify immediate adjoining villages of the mining sites,

Unit 3: villages (02) labelled in green signify villages further away from the mining sites.

Source: Author Analysis, 2017

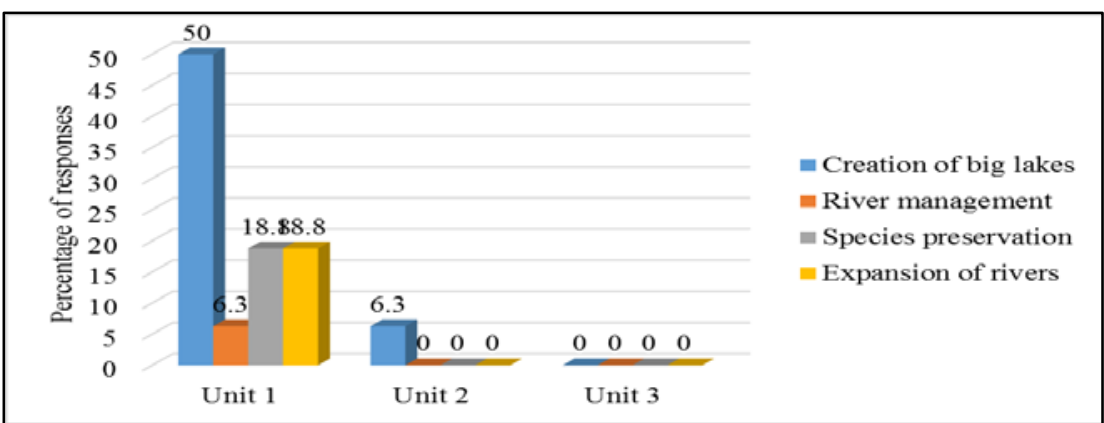

Unit 1: villages labelled in red signify active mining sites,

Unit 2: villages (03) labelled in blue signify immediate adjoining villages of the mining sites,

Unit 3: villages (02) labelled in green signify villages further away from the mining sites.

Figure 8. Responses on solutions to manage the negative impacts of mining exploitation

Table 12. Perceived effects of environmental problems associated with gold mining based on proximity to the mining areas

\begin{tabular}{lcccc}
\hline Variables & $\chi^{2}$ & Df & P & Decision \\
\hline Effects of mining on culture by proximity to the mining areas & 15.152 & 3 & 0.002 & Sig. \\
\hline Effects of mining on health by proximity to the mining areas & 27.896 & 4 & 0.000 & Sig. \\
\hline Effects of mining on education by proximity to the mining areas & 136.306 & 8 & 0.000 & Sig. \\
\hline Effects of mining on economy by proximity to the mining areas & 126.105 & 14 & 0.000 & Sig. \\
\hline Effects of mining on water quality by proximity to the mining areas & 33.901 & 8 & 0.000 & Sig. \\
\hline Effects of mining on livestock's farming by proximity to the mining areas & 14.669 & 2 & 0.001 & Sig. \\
\hline Sig.
\end{tabular}

Source: Author Fieldwork, 2017

\section{Perceived Solutions to Negative Impacts of Mining Exploitation}

Respondents were further asked to point out the practical solutions to manage the negative impacts of mining exploitation. According to respondents from villages in the active mining sites, the top issue identified was dealing with the impacts of mining as creation of big lakes $(50.0 \%)$ followed by species preservation $(18.8 \%)$ and dredging of rivers $(18.8 \%)$. These imply that all efforts should be made to reduce the impacts of mining exploitation on the quality of water especially within the active mining sites (Figure 8).

The Head of Batouri district stated that:

"The environmental impacts of gold mining can be amended through the following: at local level, creation of awareness across the active mining areas on the negative impacts of gold mining and the law enforcement agents should ensure proper application of the laws and regulations that guide mining activities at government level" (02/02/2017).

\section{Test of Hypothesis}

The perceived negative effects of gold mining on different socio-economic variables (such as culture, health, education, economy and livestock) vary significantly depending on the proximity from the mining areas.

Table 12 illustrates significant variations in the perceived environmental problems associated with gold mining on the basis of proximity to the mining areas separately. For culture, it is statistically significant $(\mathrm{p}=0.002)$. This shows that perception of the negative impacts of mining on culture varies significantly between inhabitants/villages in the active mining areas and those nearby and far away from the mining areas. For health, it is statistically significant $(\mathrm{p}=0.000)$. This points out that perception of inhabitant living and working in the active mining areas regarding the impacts of mining on the health of the populace are not the same with nearby and far away 
inhabitants from the active mining areas. Regarding education, it is statistically significant $(p=0.000)$. This suggests that perception of the environmental problems associated with gold mining vary significantly between inhabitants living and working in the active mining areas and those nearby and far away from the active mining sites. For economy, it is statistically significant $(\mathrm{p}=0.000)$. This implies that inhabitants in the active mining areas concerning their perception of the impacts of mining on economic development are not the same with those living and working nearby and far away from the active mining areas. Based on water quality, it is also statistically significant $(\mathrm{p}=0.000)$. This signifies that inhabitants in the active mining areas perceived the problems of mining on water quality differently from nearby and far away residents. Similarly, perception of the effects of mining on livestock's farming of those living in the active mining sites are not the same with those living nearby and far away from the active mining areas $(\mathrm{p}=0.001)$. The hypothesis which states that perceived environmental problems associated with gold mining vary significantly depending on the proximity from the mining areas is therefore accepted for all the socio-economic variables.

\section{CONCLUSION AND RECOMMENDATIONS}

While Cameroon's mining sector is still in its embryonic stages, semi-mechanised gold mining practiced in eastern Cameroon has led to significant and unsustainable land degradation, deforestation, health hazards, pollution of rivers and streams. Efforts of the mining companies to address their impact on host communities have been almost non-existent. Since the protection of land resources and all aspects of human security and wellbeing - food security is among the first expectations for sustainability i.e., the expectation that risks in mining will not deprive local community of their livelihoods or quality of live (health), AGM in Eastern Cameroon, therefore, has a negative implication on sustainable development. Based on foregone, the study proffers the following recommendations based on the problem identified:

1. There should be mutual commitment between the central government, local administrative authorities, stakeholders and the mining companies to curb the negative effects of gold mining on the socio-economic variables in the eastern part of Cameroon.

2. There should be enough socialization and awareness creation concerning the negative impacts of gold mining towards environmental pollution and health problems in the eastern part of Cameroon.

3. Malaria control initiative programmes should be introduced. At the same time, individual and households in the localities should be educated on the need to use mosquito nets in their rooms to avoid malaria infections through mosquitoes biting in the eastern part of Cameroon.

4. Companies involved in mining activities should embark on development projects such as portable water, schools, hospitals, good roads, markets, communications facilities within the mining sites in the eastern part of Cameroon.

5. Government should therefore be more concerned and committed to the sustainability of the physical environment in both the rural and urban area and not only the sustainability and survival of the economy in the eastern part of Cameroon.

If all these steps are taken, then the problems associated with gold mining activities in the study area would actually be minimized and this may in turn have a great influence on the overall development of socio-economic variables and therefore the living standards of people living in the local government area would improve greatly.

\section{SUGGESTED AREAS FOR FURTHER RESEARCH}

Further study could replicate this study in other areas across the country in mining areas for better understanding of the current situation between them.

Further studies can be carried out to investigate the relationship between gold mining activities and increased incidences of diseases such as malaria, Diarrhoea, Typhoid fever, HIV/AIDS, and prostitution in the eastern part of Cameroon. There is need to investigate the relationship between gold mining and economy development of the eastern Cameroon.

\section{ACKNOWLEDGEMENTS}

The authors are grateful to the individual respondent from regional and departmental delegations of mining and environment and the local communities of Bétaré-Oya, Ngoura and Batouri districts in eastern Cameroon for their patience, time they sacrificed and relevant information provided on this research paper. This write up constitutes part of data generated during the Ph.D study of the corresponding author, at the Pan African University Life and Earth Science Institute. We also thank reviewers for constructive comments that helped to improve an 
earlier manuscript version. The Ph.D. programme of Mr. KAMGA Marc Anselme is being funded by African Union through Pan African University, Institute of Life and Earth Sciences (including Health and Agriculture), University of Ibadan, Nigeria

\section{REFERENCES}

Adekoya, J. A. (2003). Environmental effect of solid minerals mining. Journal of Physical Sciences, Kenya, 625-640.

Aigbedion, I. N. (2005). Environmental Pollution in the Niger Delta, Nigeria. Inter-Disciplinary Journal, 3(4), 205-10.

Ajakaiye, D. E. (1985, May). Environmental problems associated with mineral exploitation in Nigeria. In A paper presented at the 21st annual conference of the Nigeria Mining and Geosciences Society beld at Jos (Vol. 140148).

Awudi, G. B. (2002, February). The role of foreign direct investment (FDI) in the mining sector of Ghana and the environment. In Conference on Foreign Direct Investment and the Environment, OECD, Paris.

Asaah, V. A. (2010). Lode gold mineralisation in the Neoproterozoic granitoids of Batouri, southeastern Cameroon (Doctoral dissertation, Zugl.: Clausthal-Zellerfeld, Techn. Univ., Diss., 2010).

Ayuk, A. E. (2001). Center-periphery relations in the context of political reforms in Africa: a study of Cameroon (1972-1997). ETD Collection for AUC Robert W. Woodruff Library. 2198.

Borralho, C. (2013, August 2). Gold mining affects mineworkers' health.

Brooks, D. B. (1974). Conservation of Mineral and of the Environment. Office of Energy Conservation. Canadian Department of Energy, Mines and Resources, Ottawa, Canada. pp. 80-91.

Bryman, A. (2012). Sampling in qualitative research. Social research methods, 4, 415-429.

BUCREP, 3 ème RGPH (2010). La population du Cameroun en 2010.

Cameroon mining guide (2014). p.1-28

Chachange, C. S. L. (1995). Mining and environmental issues under SAPs in Tanzania: examples from three case studies. In: Bagachwa MSD, Limbu F, editors. Proceedings of the policy reforms and the environment in Tanzania (Dar es Salaam, Tanzania), p. 251.

Central Intelligence Agency (CIA). (1999). The World Factbook 2009. Cameroon. Available at: https://www.cia.gov/library/publications/resources/the-world-factbook/geos/cm.html

Coe, M. T. and Foley, J. A. (2001). Human and natural impacts on the water resources of the Lake Chad basin. Journal of Geophysical Research: Atmospheres, 106(D4), 3349-3356. https://doi.org/10.1029/2000JD900587

Drebenstedt, C. (2008). Responsible mining-approaches and realization. In Proc. 22nd World Mining CongressInnovations and Challenges in Mining (Vol. 1, pp. 135-147).

Dubiński, J. (2013). Sustainable development of mining mineral resources. Journal of Sustainable Mining, 12(1), 1-6. https://doi.org/10.7424/jsm130102

Duraiappah, A. K. (1998). Poverty and environmental degradation: a review and analysis of the nexus. World development, 26(12), 2169-2179. https:// doi.org/10.1016/S0305-750X(98)00100-4

Gabche, C. E. and Folack, J. (1997). Cameroon coastal river network and its impact on the coastal and marine environment. 27th Liege Colloquim on Ocean Hydrodynamics. Liege Belgium, 8-12 May 1995 (No. 9, p. 12). IRMA Report.

Gaston, B. W. (2009). Geographic information systems based demarcation of risk zones: the case of the Limbe Sub-Division-Cameroon. Jàmbá: Journal of Disaster Risk Studies, 2(1), 54-70. https://doi.org/10.4102/jamba.v2i1.15

Gazel, J. and Gerard, G. (1954). Carte géologique de reconnaissance du Cameroun au 1/500000, feuille de BatouriEst avec notice explicative. Mémoire Direction des Mines et de la Géologie, Yaoundé, Came-roun.

Gellert, P. K. and Lynch, B. D. (2003). Mega - projects as displacements. International Social Science Journal, 55(175), 15-25. https://doi.org/10.1111/1468-2451.5501002

George M. W. (2009). USGS Minerals yearbook 2007: Gold. U.S. Department of the Interior, US Geological Survey, Washington D.C.

Jasna, P. and Đurđević, J. (2011). The use of mineral resources and issues of harmonization between spatial plans for the mining areas in Serbia with other strategic documents. Spatium, 24, 21-26.

Jason, S. O., Winnie, V. M. and Monica, A. O. (2002). Impact of gold mining on the environment and human health: a case study in the Migori gold belt, Kenya. Environmental Geochemistry and Health, 24(2), 141-157. https://doi.org/10.1023/A:1014207832471

Jimoh, I. H. (2006). Pattern of environmental degradation and development efforts. Democracy and Development in Nigeria: Economic and Environmental Issues, 2.

Mafany, G. T., Fantong, W. Y. and Nkeng, G. E. (2006). Groundwater quality in Cameroon and its vulnerability to pollution. Groundwater pollution in Africa. Taylor \& Francis, London, 47-55.

Makweba, M. M. and Ndonde, P. B. (1996). The mineral sector and the national environmental policy. In Proceedings of the workshop on the national environmental policy for Tanzania (Dar es Salaam, Tanzania) (pp. 73-164).

(C) 2018 by Author/s 
Malm, O. (1998). Gold mining as a source of mercury exposure in the Brazilian Amazon. Environmental Research, 77(2), 73-78. https:/ / doi.org/10.1006/enrs.1998.3828

Marsh, G. P. (1864). Man and Nature; or. Physical geography as modified by human action, 35.

McMahon, G. and Remy, F. (Eds.). (2001). Large mines and the community: socioeconomic and environmental effects in Latin America, Canada, and Spain. Idrc.

Miller, R. L. and Brewer, J. D. (Eds.). (2003). The AZ of social research: a dictionary of key social science research concepts. Sage. https:// doi.org/10.4135/9780857020024

Moody, R. and Panos, S. P. (1997). Environmental assessment of mining projects.

Muezzinoglu, A. (2003). A Review of Environmental Considerations on Gold Mining and Production. Critical reviews in environmental science and technology, 33 (1), pp. 45-71. https:/ / doi.org/10.1080/10643380390814451

Myriam, M. E. and Christophe, D. B. (2011). Identification of hazards in the workplaces of artisanal mining in Katanga. International journal of occupational medicine and environmental health, 24(1), 57-66.

National Climatic Data Center (NCDC). (2015). Highest Average Annual Precipitation Extremes. Global Measured Extremes of Temperature and Precipitation, August 9, 2015. (Accessed 7 May 2017).

Nodem F. R. (2016). An Assessment of the impacts of mining activities on water resources and environment in the Kadey division, Eastern Cameroon. Pan African University, PAULESI, Ibadan, Nigeria. Master thesis, 125p.

Noronha, L. (2001, February). Designing tools to track health and well - being in mining regions of India. In Natural resources forum (Vol. 25, No. 1, pp. 53-65). Blackwell Publishing Ltd. https://doi.org/10.1111/j.14778947.2001.tb00746.x

Opara, J. A. (2009). Urban Waste Management in Port Harcourt Metropols of the Niger Delta Region in Nigeria. Available at: http://www.businessschool.infor/...site../updated _version_of_UCN.org (Accessed 20 November 2017).

Onuoha, F. C. (2008). Oil Exploitation, Environmental Degradation and Climate Change: Assessing the Vulnerability of the Niger Delta to Natural Disasters. In Conference Proceedings of the International Conference on the Nigerian State, Oil Industry and the Niger Delta. Port Harcourt: Harey Publications Company.

Pegg, S. (2003). Poverty reduction or poverty exacerbation. World Bank Group support for extractive industries in Africa. Report sponsored by Oxfam America, Friends of the Earth-US, Environmental Defense, Catholic Relief Services, Bank Information Center, Washington, D.C.

Seydou, K. (2002). Study on artisanal and small-scale mining in Mali. Mining, Minerals and Sustainable Development (MMSD) Working Paper, 80.

Søndergaard, J., Asmund, G., Johansen, P. and Rigét, F. (2011). Long-term response of an arctic fiord system to lead-zinc mining and submarine disposal of mine waste (Maarmorilik, West Greenland). Marine Environmental Research, 71(5), 331-341. https:/ / doi.org/10.1016/j.marenvres.2011.03.001

Stallins, J. A. (2007). The Biogeography of Geographers: A Content Visualization of Journal Publications. Physical Geography, 28(3), 261-275. https://doi.org/10.2747/0272-3646.28.3.261

Stephens, C. and Ahern, M. (2001). Worker and community health impacts related to mining operations internationally: a rapid review of the literature. London: London School of Hygiene \& Tropical Medicine.

Tauli-Corpuz, V. (1998). The globalisation of mining and its impact and challenges for women. Third World Resurgence, 29-32.

Tetsopgang S., Nzolang C. and Kuepouo G. (2007). Environmental and Socio-economic assessment of an Artisanal Gold Mine Field: Case of Betare-Oya, Eastern Cameroon. Cameroon: Centre de Recherche et d'éducation pour le Développement (CREPD), P.O. Box 3134, Yaoundé.

Tobler, W. R. (1970). A computer movie simulating urban growth in the Detroit region. Economic geography, 46(sup1), 234-240. https:/ / doi.org/10.2307/143141

Traore, B. A, (2015). The management of environmental impacts of gold mining during operational phase of mining sites in Mali: Case study of Sikasso region in the South. Department of Environmental Management. Pan-African University, Univ. of Ibadan. Nigeria, Master, July 2015; p.167

Tsalefac, M. (2007). Climate. In: Houstin, N., Seignobos, C. (Eds.), Atlas of Cameroon. Les Éditions Jeune Afrique, Paris, pp. 62-63.

UNIDO. (2001). Media Corner, Feature: Artisananl gold mining without mercury pollution. Available at: http://www.unido.org/doc/371455.htmls

United Nations Environment Programme (UNEP). (1997). Industry and environment, mining and sustainable development. Available at: http:/ /www.uneptie.org/vol20no4.htm

Wolanski, N. and Siniarska, A. (2005). A model for human ecology. Departamento de Ecología Humana, Centro de Investigacion y de Estudios Avanzados Del IPN, Unidad Merida, Mexico and Department of Human Biology, Human Ecology Unit, Cardinal Stefan Wyszyński University, Warsaw, Poland.

World Resources Institute. (2014). Atlas forestier interactif du Cameroun. Yaoundé: MINEPDED/WRI. 